\title{
Seasonal patterns in bacterioplankton abundance and production in Narragansett Bay, Rhode Island, USA
}

\author{
Andrew M. Staroscik ${ }^{1,2, *}$, David C. Smith ${ }^{1}$ \\ ${ }^{1}$ Graduate School of Oceanography, University of Rhode Island, Narragansett, Rhode Island 02882, USA \\ ${ }^{2}$ Present address: Department of Cell and Molecular Biology, 117 Morrill Science Building, University of Rhode Island, \\ Kingston, Rhode Island 02881, USA
}

\begin{abstract}
Bacterial abundance and production were measured weekly for 34 mo consecutively at 2 stations in Narragansett Bay, Rhode Island, a well mixed temperate estuary. Data from the more centrally located station were used to describe the relationship between temperature, bacterial abundance and bacterial production over the annual cycle. During the entire sampling period, temperature ranged from -1.0 to $22.6^{\circ} \mathrm{C}$, bacterial abundance varied by a factor of 16 and bacterial production by a factor of 101. Significant correlations of temperature on bacterial abundance and production $(p<0.05)$ highlight the strong seasonality of bacterial activity in the bay. After controlling for temperature, both bacterial abundance and production were significantly higher in the spring than in the fall, suggesting that the relationship between temperature and the populations present is different during these 2 seasons. No significant relationships were found between the bacterial bulk parameters and concentrations of chl a. Data from both stations were used to calculate annual net bacterial production values of 83 and $68 \mathrm{~g} \mathrm{C} \mathrm{m}^{-2} \mathrm{yr}^{-1}$ for the mid- and lower bay, respectively. Gross bacterial carbon demand (production + respiration) at the mid-bay station was estimated at $\sim 237 \mathrm{~g} \mathrm{C} \mathrm{m}^{-2} \mathrm{yr}^{-1}$, which is roughly $94 \%$ of previous estimates of bay-wide, net phytoplankton primary production.
\end{abstract}

KEY WORDS: Bacterioplankton $\cdot$ Regulation $\cdot$ Temperature $\cdot$ Narragansett Bay

\section{INTRODUCTION}

In aquatic systems such as the Narragansett Bay, bacterioplankton communities play an important role in biogeochemical cycles due to their large numbers and high turnover rates. Many factors act to control bacterial activity, two of which are temperature and substrate availability. The relative importance of the two is not well understood (Hoch \& Kirchman 1993), and there is evidence that the interactive effects of temperature and substrate supply are different in different aquatic environments (Pomeroy \& Wiebe 2001). In a mesocosm enrichment study using Narragansett Bay water, Hobbie \& Cole (1984) found strong correlations between temperature and phytoplankton biomass (chl a concentration) on bacterial secondary production. A goal of this present work was to attempt to understand the relative importance of temperature and phytoplankton biomass on observed variability in bacterial abundance and growth in Narragansett Bay, using a field sampling regime.

In areas where water temperatures are low only in the winter, bacterial communities are strongly influenced by temperature (Sieburth 1967, Simon \& Wünsch 1998). The importance of temperature in these systems has been inferred from strong correlations of temperature on bacterial abundance and production. Use of temperature-shift experiments (the artificial raising and/or lowering of water temperature during incubations) suggests that in temperate coastal areas at low temperatures, temperature, and not substrate availability, limits bacterial productivity (Hollibaugh 1979, Pomeroy et al. 1991, Shiah \& Ducklow 1994a, Autio 1998, Simon \& Wünsch 1998). A general conclusion of this research is that when water temperatures are low, bacteria are unable to fully utilize the organic carbon present in the environment (Nedwell 1999). In a survey of 57 studies of aquatic systems, White et al. 
(1991) found that the correlation between bacterial activity and temperature was greater in coastal and estuarine environments, compared to freshwater and open ocean locations.

Studies of the seasonal dynamics of bacterioplankton in estuaries typically sample at monthly intervals or less (Wright \& Coffin 1983, Hoch \& Kirchman 1993, Shiah \& Ducklow 1994a). In an effort to better observe temporal variability, sampling for this study of Narragansett Bay was performed at weekly intervals. Narragansett Bay is a well mixed northern temperate estuary; it has a mixed semidiurnal tidal regime with a mean tidal range of ca. $1.2 \mathrm{~m}$ (Kremer \& Nixon 1978). Daily freshwater input equals ca. $0.3 \%$ of the bay's total volume. Mean salinity is approximately 30 and the residence time ranges from 10 to $40 \mathrm{~d}$, with a mean of 26 (Pilson 1985). The annual temperature range is -1 to $25^{\circ} \mathrm{C}$. A significant relationship between bacteria and phytoplankton was expected because carbon budgets constructed for Narragansett Bay have shown that in situ primary production by phytoplankton is responsible for $>80 \%$ of the organic carbon available (Nixon et al. 1995), and correlations were found in a mesocosm study using Narragansett Bay water (Hobbie \& Cole 1984).

The weekly sampling regime generated a large dataset, and relationships between in situ water temperatures and bacterial abundance and production were assessed using regression analysis. The data were also used to determine whether there is a temperature above which the relationship is less robust, as found by Hoch \& Kirchman (1993) for Delaware Bay. Annual bacterial production was estimated and compared to previously reported estimates of phytoplankton primary production. Finally, since the focus of the analysis was on data collected from one location in the bay, samples collected at other locations within the bay were used to assess the spatial variability in bacterioplankton abundance and production.

\section{MATERIALS AND METHODS}

Weekly sampling was performed in the West Passage, near Fox Island $\left(41^{\circ} 34.24^{\prime} \mathrm{N}, 71^{\circ} 24.34^{\prime} \mathrm{W}\right)$, and off the dock at the Graduate School of Oceanography (GSO, 41 ${ }^{\circ} 29.53^{\prime} \mathrm{N}, 71^{\circ} 25.12^{\prime} \mathrm{W}$ ) (Fig. 1). These stations are $9 \mathrm{~km}$ apart. The Fox Island station is the site of a long-term weekly sampling program for phytoplankton abundance and species composition (Karentz \& Smayda 1984, Smayda 1985).

Sampling was performed from September 1999 through June 2002. Water was collected in acidcleaned $1 \mathrm{l}$ polycarbonate flasks from the top $1 \mathrm{~m}$ of the water column. In August and September 2000, Fox

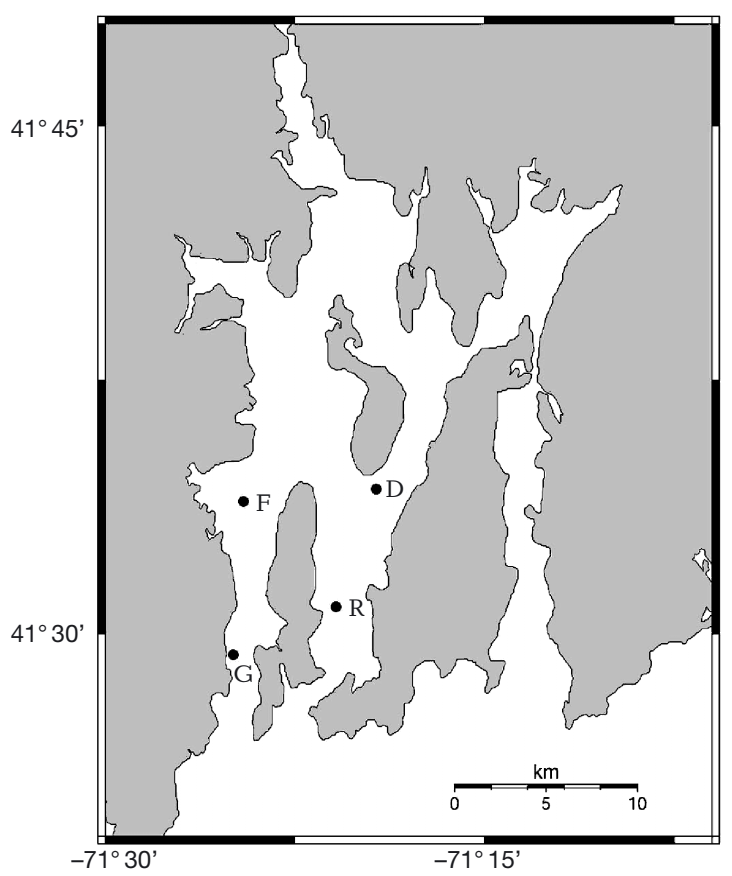

Fig. 1. Map of Narragansett Bay indicating Fox Island (F), Dyer Island (D), Rose Island (R), and the Graduate School of Oceanography (GSO) Dock (G) stations

Island and a station $\sim 100 \mathrm{~m}$ off the GSO dock, as well as 2 other stations (Dyer Island and Rose Island; Fig. 1), were sampled at 1 to $7 \mathrm{~d}$ intervals. Surface water was collected as described above, and water from $\sim 1 \mathrm{~m}$ above the bottom was collected using a 51 Niskin bottle. Water depths were: Fox Island $9 \mathrm{~m}$, Dyer Island $27 \mathrm{~m}$, GSO $14 \mathrm{~m}$ and Rose Island $37 \mathrm{~m}$. Water was transported back to the laboratory in acid-cleaned $1 \mathrm{l}$ glass lined thermoses and analyses were performed within 2 h of sampling. On 26 May 2002, 8 samples were taken at 1 to $2 \mathrm{~h}$ intervals off of the GSO dock to document variability in bacterial abundance and production over the tidal cycle.

Samples for bacterial abundance were fixed with formalin ( $2 \%$ final concentration) and sonicated at $10 \mathrm{~W}$ for $30 \mathrm{~s}$ after the addition of a surfactant (Tween 80, Fisher Scientific) (Yoon \& Rosson 1990). One to $2 \mathrm{ml}$ of sample were filtered onto $25 \mathrm{~mm}$ diameter, $0.02 \mu \mathrm{m}$ pore-sized alumina matrix filter (Anodisc, Whatman) and stained with the DNA fluorescent dye SYBR Green I (Molecular Probes) (Noble \& Fuhrman 1998). Bacteria were enumerated using epifluorescent microscopy (1250× magnification).

Bacterial growth was measured using the ${ }^{3} \mathrm{H}$-labeled leucine method (Kirchman et al. 1985) as modified for centrifugation by Smith \& Azam (1992). Saturation curves performed at 3 different times of the year indicate that $20 \mathrm{nM}$ was saturating (data not shown). ${ }^{3} \mathrm{H}$-leucine incorporation was converted to $\mu \mathrm{g} \mathrm{Cl}^{-1} \mathrm{~d}^{-1}$, 
assuming $3.1 \mathrm{~kg} \mathrm{C} \mathrm{mol} \mathrm{m}^{-1}$ of leucine incorporation (Simon \& Azam 1989). Bacterial specific growth rates (SGR) were estimated assuming $20 \mathrm{fg} \mathrm{C}$ per bacterial cell (Lee \& Fuhrman 1987).

Chl a concentration was determined by filtering $25 \mathrm{ml}$ of water through $25 \mathrm{~mm}$ diameter glass fiber filter (GF/F, Whatman) and stored at $-20^{\circ} \mathrm{C}$ in the dark until processing. Pigments were extracted in $10 \mathrm{ml}$ of $90 \%$ acetone for $24 \mathrm{~h}$ in the dark with refrigeration and measured fluorometrically (Yentsch \& Menzel 1963). Chl a concentrations were calculated using the equations of Lorenzen (1966).

For all statistical analyses, chl a and bacterial abundance, production and SGR values were $\log (x+1)$ transformed to normalize variance (Zar 1999). Assumption of the normality of the transformed data

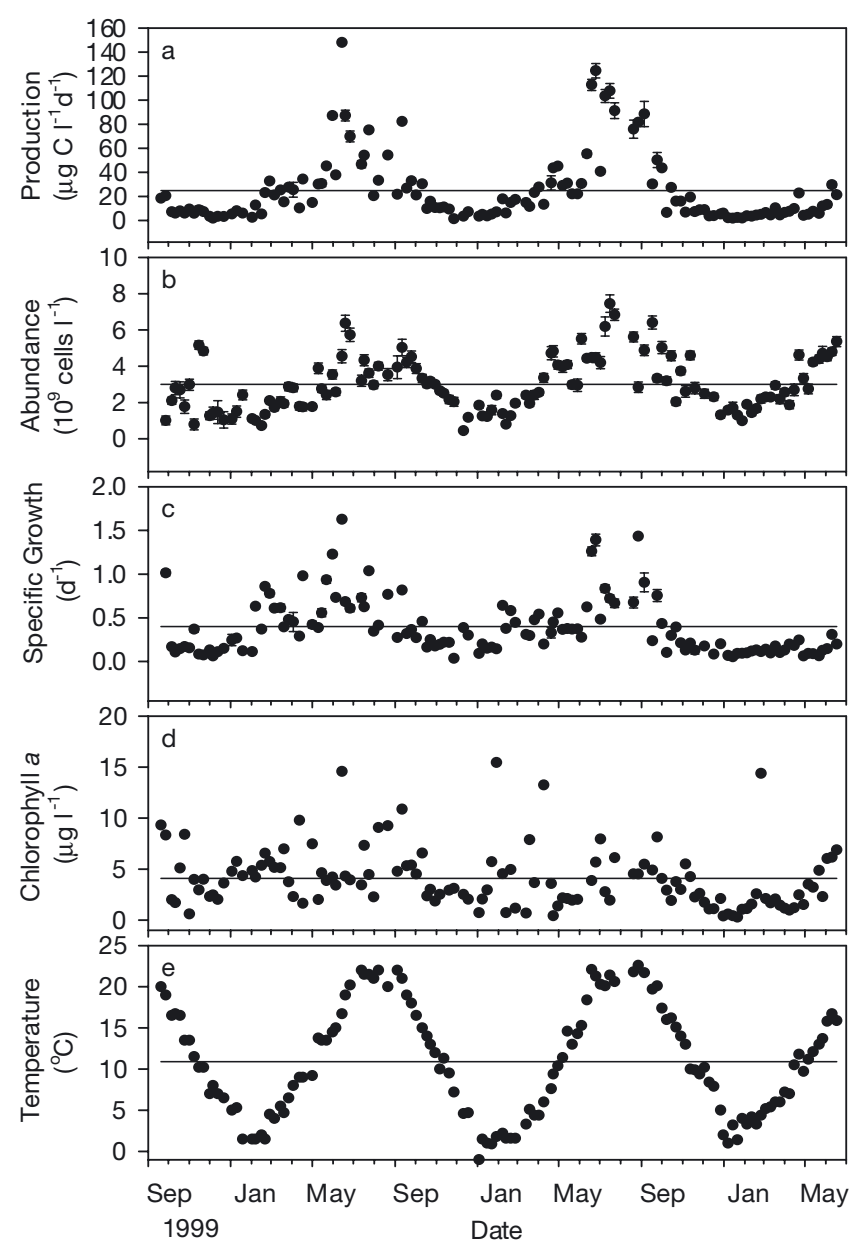

Fig. 2. Summary of the entire 34 mo dataset for (a) bacterial production, (b) bacterial abundance, (c) bacterial specific growth, (d) chl a and (e) temperature. The solid line represents the mean value over the entire dataset. Error bars for production and abundance are $95 \%$ confidence intervals. Error bars for specific growth are SDs for each measurement. Some error bars are smaller than the symbols. No error bars are shown for chl a or temperature was tested using the Kolmogrov-Smirnov 1-sample test for goodness-of-fit against a hypothesized normal distribution. Relationships between the bacterial bulk parameters and other parameters were tested using simple linear regressions. Regressions were Type II models, assuming equal error in the $x$ and $y$ variables. For the overall regression analyses, the test statistics were adjusted to account for the autocorrelation inherent in time-series data (Bence 1995, Pyper \& Peterman 1998).

In order to estimate autocorrelation values for each parameter, gaps and unequal time steps were removed by interpolating between existing points. This added 14 additional points to the data set. These points were used for estimating autocorrelation values and were removed prior to all subsequent analyses.

Some analyses were preformed using a subset of the entire time series binned by season. Determining autocorrelation in these subsets was not possible due to data gaps, so randomization testing (Manly 2001) was done to determine whether the differences between seasons seen in the simple regression analysis were robust. In this analysis, samples from different times of the year were grouped by season and test statistics calculated. The samples were then randomly assigned to each category (season) and the test statistics recalculated. The randomization was repeated 4999 times, creating 5000 independent samples with a normal distribution. The position of the original sorted data within the normal distribution was then used to determine how likely the values were to occur by chance alone (Manly 2001).

Bacterial production estimates were grouped by month and integrated to $8 \mathrm{~m}$ (average depth of the bay) (Pilson 1985) and compared to previous estimates of phytoplankton primary production.

\section{RESULTS}

Bacterial abundance, production, chl a and water temperature were collected weekly and SGR calculated for 34 mo at Fox Island (Fig. 2). All 3 bacterial parameters varied with seasonal changes in temperature. Chl a did not show the same degree of seasonal variation, with high concentrations appearing in both the spring and summer. The temperature range over the sampling period was -1.0 to $22.6^{\circ} \mathrm{C}$, with a mean and standard error (SE) of $10.9 \pm 0.6$. Chl a ranged from 0.3 to $15.5 \mathrm{\mu g} \mathrm{l}^{-1}$, with a mean of $4.1 \pm 0.3(\mathrm{SE})$. Of the bacterial parameters, bacterial production showed the greatest amount of variability, ranging from 1.4 to $147.9 \mu \mathrm{g} \mathrm{C}^{-1} \mathrm{~d}^{-1}$, with a mean of $24.8 \pm 2.5(\mathrm{SE})$. Bacterial abundance was less variable, ranging from 0.4 to $7.5 \times 10^{9}$ cells $^{-1}$, with a mean of $3.0 \pm 0.1 \times 10^{9}(\mathrm{SE})$. 
For regressions, missing data were eliminated pairwise, resulting in a range of sample sizes from 123 to 131. After adjusting for autocorrelation, temperature showed significant correlations with the bacterial production $(p=0.007)$ and abundance $(p=0.004)$, but not with SGR ( $p=0.09)$ (Fig. 3). There were no significant relationships between either chl $a$ or total phytoplankton cell counts and any of the bacterial bulk parameters.

Seasonal differences in the relationships among these parameters were examined by focusing on periods when water temperatures were between 5 and $15^{\circ} \mathrm{C}$. Samples in this temperature range were separated into late winter/spring (February through June) and fall/early winter (September through December) bins, and the regressions rerun. The results of the randomization tests were similar to those of the simple regressions, showing that the best-fit regression lines of temperature on production and abundance
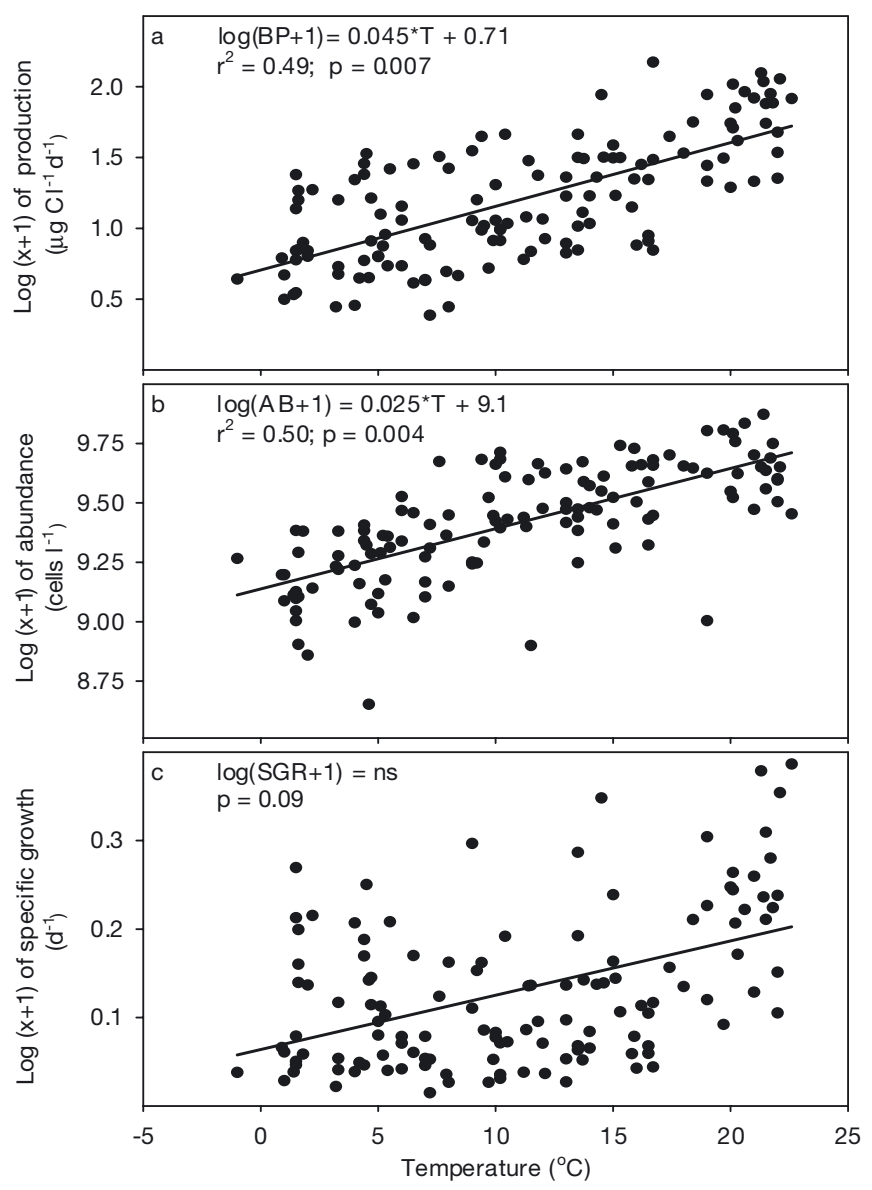

Fig. 3. Linear regressions of temperature on the $\log (x+1)$ transformed data for (a) bacterial production, (b) abundance and (c) specific growth rate (SGR). Regression equations are shown in each panel; the slope of the regression of temperature on SGR was not significant
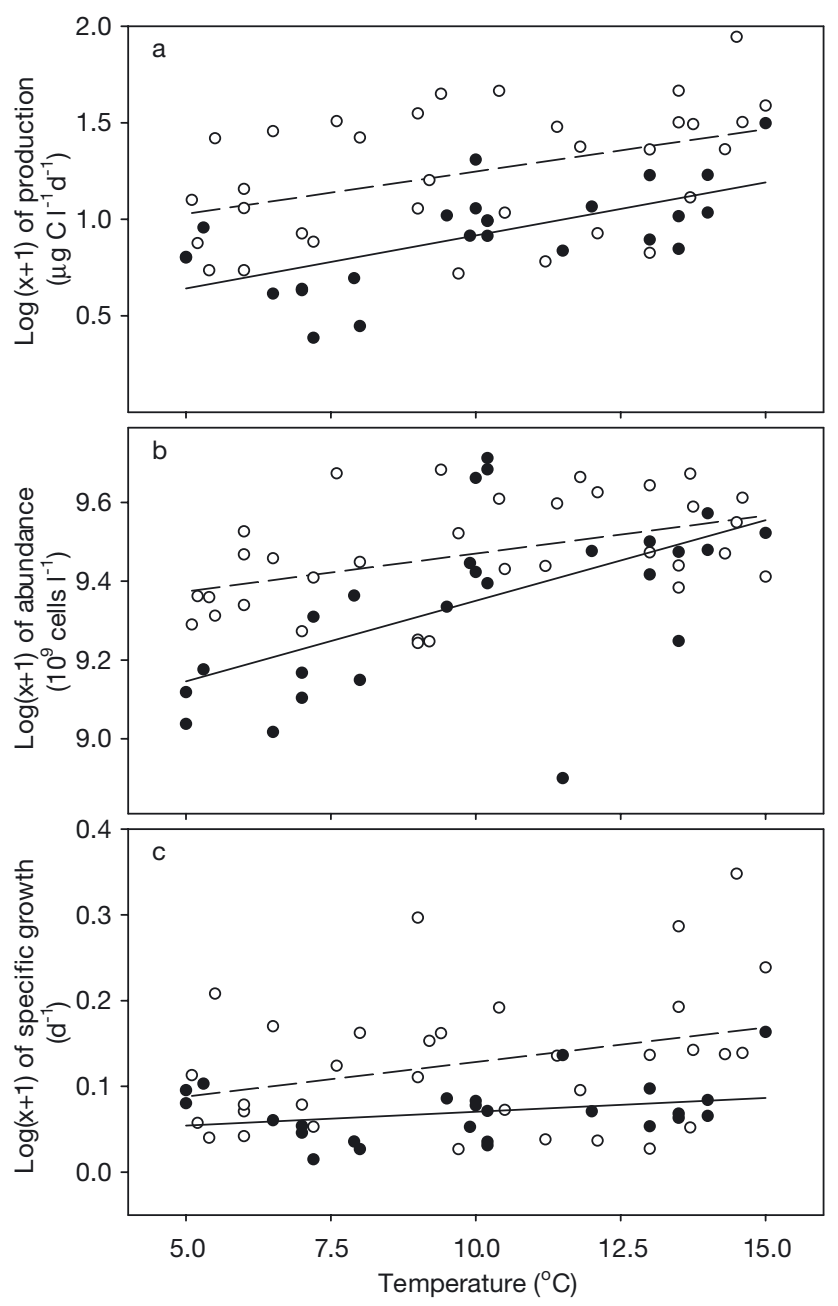

Fig. 4. Linear regressions of temperature on the $\log (x+1)$ transformed data for (a) bacterial production, (b) abundance and (c) specific growth rate (SGR) for spring (O) and fall (•) data in the 5 to $15^{\circ} \mathrm{C}$ temperature range. The dashed line is the regression line for the spring data and the solid line is for fall data. The slopes of the lines are not statistically different, but the lines for abundance and production are not coincident

were significantly different for the spring and fall data bins $(p=0.02$ and 0.003 for production and abundance, respectively) (Fig. $4 \mathrm{a}, \mathrm{b}$ ). None of the relationships with chl $a$, nor the relationship between temperature and SGR, were significant $(p>0.05)$ (Fig. 4c).

Using the 34 mo of weekly data from Fox Island station, total annual bacterial production was $83 \mathrm{~g} \mathrm{C} \mathrm{m}^{-2}$ $\mathrm{yr}^{-1}$. Comparison of the Fox Island and GSO dock datasets shows that overall, bacterial production in the mid-bay is higher than the lower bay (83 and $68 \mathrm{~g} \mathrm{C}$ $\mathrm{m}^{-2} \mathrm{yr}^{-1}$, respectively). These 2 stations appear to covary, with the least-squares regression line in Fig. 5a falling close to the 1:1 line. 
In the 4-station data set from late summer 2000, the highest production value was $142 \mu \mathrm{g} \mathrm{C} \mathrm{l}^{-1} \mathrm{~d}^{-1}$ at the surface at Dyer Island station on 11 August, and the

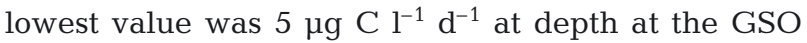
Channel station on 31 August. The presence of a down-bay gradient is suggested by this shorter summer 2000 dataset, with every point in Fig. 5b falling on the mid-bay side of the 1:1 line. The 2000 summer data also suggest that north-south variability is greater and more consistent than along the east-west axis (Fig. 5c), and that surface production is higher than at depth (Fig. 5d). On average, production at GSO was $57 \%$ of the production at Fox Island, and Rose Island was 51\% of Dyer Island production. In the east-west direction, the average difference is not as great, with Fox Island being $95 \%$ of Dyer Island and Rose Island being $91 \%$ of GSO.

During the tidal cycle sampled on 26 May 2002,

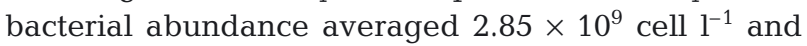

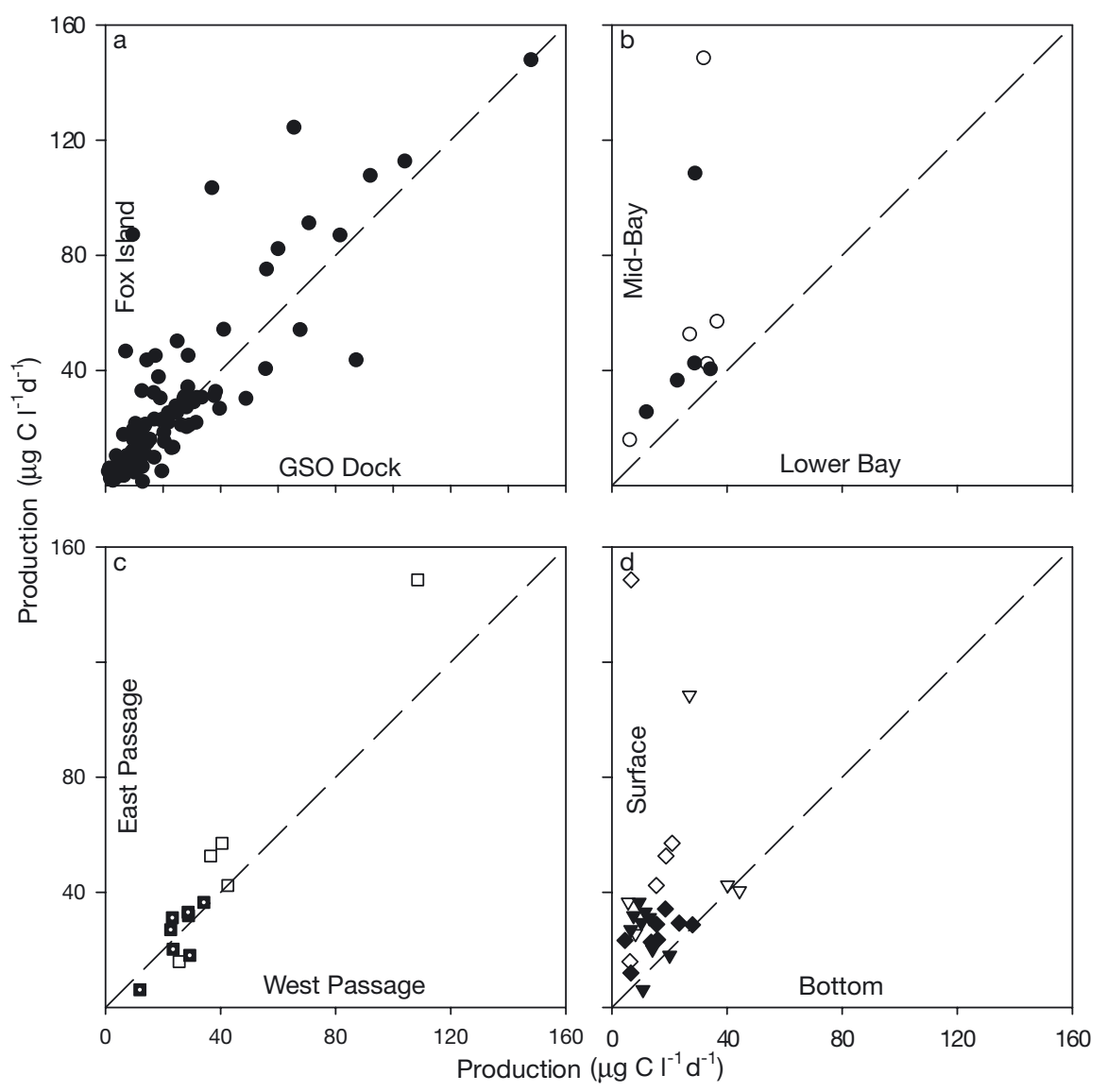

Fig. 5. Scatter plots illustrating the ratio of bacterial secondary production: (a) over the entire 34 mo time series, between Fox Island and the Graduate School of Oceanography (GSO) Dock station, and $(b-d)$ during the summer 2000 sampling between (b) lower and mid-bay, (c) west and east passage, and (d) surface and bottom waters. Symbols: (•) Fox vs GSO, (0) Dyer vs Rose,

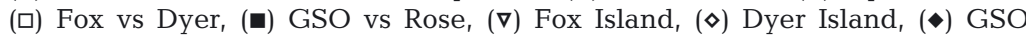
Channel and ( $\mathbf{\nabla})$ Rose Island ranged from 2.60 to $3.01 \times 10^{9}$ cell $\mathrm{l}^{-1}$. Average bacterial production was $1.10 \times 10^{-5} \mathrm{~g} \mathrm{C} \mathrm{l}^{-1} \mathrm{~d}^{-1}$ and ranged from $9.06 \times 10^{-6}$ to $1.29 \times 10^{-5} \mathrm{~g} \mathrm{C} \mathrm{l}^{-1} \mathrm{~d}^{-1}$. Abundance varied very little over the sampling period, and the changes in bacterial production appear to be driven more by the $1^{\circ} \mathrm{C}$ temperature change that occurred during sampling than the change in the stage of the tide (data not shown).

\section{DISCUSSION}

\section{Seasonal patterns in bacterial activity}

The bacterial community in Narragansett Bay showed strong seasonality. Both abundance and production varied with temperature, peaking in late June or early July and remaining high until the water temperature began to decline in September. The standard interpretation of this pattern is that it is a result of the overriding importance of temperature in determining bacterial activity in aquatic ecosystems (Hoch \& Kirchman 1993, Shiah \& Ducklow 1994b, Autio 1998, Pomeroy \& Wiebe 2001). Studies from other temperate estuaries suggest that there maybe a temperature below which bacterial activity is more strongly influenced by changes in temperature, and it is only when water temperatures rise above some threshold that other factors such as substrate availability become important (Shiah \& Ducklow 1994b). This threshold temperature was apparent in a data set from Delaware Bay as a break in the regression of temperature on bacterial specific growth at $12^{\circ} \mathrm{C}$ (Hoch \& Kirchman 1993). In Narragansett Bay, there is no apparent break in production, abundance or SGR (Fig. 3), suggesting that the bay's bacterioplankton community does not become substrate limited in summer.

A comparison of spring and fall data shows that bacterial abundance and production tend to be higher in spring relative to fall at any given temperature (Fig. 4a,b). A difference is also suggested in the regressions of temperature on SGR, with spring values being generally higher and more variable than the fall values (Fig. 4c), but the differences are not statistically significant. Bacterial populations in Narragansett 
Bay may undergo adaptation to different temperature regimes over the annual cycle. Adaptation in biological systems is known to occur at many scales, and the term has been used to describe a variety of responses to changing environmental conditions (Prosser 1986). In the context of aquatic microbial populations and temperature variability, it has been used to describe a process by which an organism (Li \& Morris 1982) or community (Li \& Dickie 1987, Simon \& Wünsch 1998) compensates for changes in temperature in such a way that metabolic processes are able to be maintained at relatively constant rates over a range of temperatures (Li \& Morris 1982). In this study, the higher values in the bacterial bulk parameters in the spring compared to the fall could result from differences in the response of populations present in these 2 seasons to changing temperatures. The spring population experiences warming after having had the opportunity to adapt to low temperatures, while the opposite is true of the fall population.

The overall relationship between temperature and SGR is not as strong as those seen for abundance and production (Fig. 3). This may be because, as a derived parameter, SGR is the least precisely estimated due to the error in each of the measured parameters being compounded in the derived one. Because no estimates of bacterial cell biomass were made, the use of a single conversion factor may introduce additional error. The lack of a relationship between SGR and temperature supports the idea that the bacterial community is undergoing temperature adaptation because the growth of individual bacterial cells varies less over the annual cycle than do production and abundance. This is further supported by the seasonal data which indicate that SGR is higher in spring relative to fall, although the differences are not significant, as the slopes of neither seasonal regression is different from zero at a p-value of 0.05 .

In the Delaware Bay, Coffin \& Sharp (1987) observed that while bacterial production remained high over the summer months, abundance was kept low by microflagellate grazing. Bactivory was not quantified in this study, but it may have contributed to the lower fall abundance and production values (Fig. 4). In addition to grazing, the reduced rates of fall bacterial production may result from bacterioplankton having consumed enough of the available organic carbon to become substrate rather than temperature limited. The data available do not allow us to distinguish among these factors, and it is likely that grazing, viral lysis, substrate availability and temperature adaptation all play a role in the observed pattern.

Mesocosm studies have shown clear correlations between patterns in bacterial and phytoplankton activity (Hobbie \& Cole 1984, Smith et al. 1995). However, these findings are difficult to reproduce with field sampling. While it is believed that in estuarine environments such as Narragansett Bay a significant fraction of bacterial production is dependent upon phytoplankton primary production (Ducklow and Shiah 1993), the lack of correlations in field sampling illustrate limitations of the standard methods used to measure the activity and abundance of bacteria and phytoplankton. The response of bacteria to phytoplankton is not instantaneous; rather, bacterial activity is dependent upon the activity of phytoplankton over some previous period of time. Even weekly sampling does not appear to capture this relationship.

\section{Annual bacterioplankton secondary production}

This study provides the first estimates of bacterial secondary production in Narragansett Bay from field samples over the annual cycle. There were no concurrent measurements of primary production during our study, but a previous estimate of gross phytoplankton primary production from Narragansett Bay is $323 \mathrm{~g} \mathrm{C}$ $\mathrm{m}^{-2} \mathrm{yr}^{-1}$ (Oviatt et al. 2002). Although the bacterial production and phytoplankton primary production measurements were not performed over the same time period, contrasting these 2 datasets does provide an insight into the relative activities of these 2 components of the planktonic community, and illustrates the significance of water column bacterial carbon consumption.

The ratio of bacterial production to phytoplankton production is 0.26 , which is in good agreement with the general pattern in aquatic systems. Cole et al. (1988) found that bacterial secondary production represented a fairly consistent fraction of phytoplankton primary production across a wide range of aquatic systems, and was, on average, $\sim 30 \%$ of phytoplankton primary production.

Oviatt et al. (2002) estimated that the gross primary production of $323 \mathrm{~g} \mathrm{C} \mathrm{m}^{-2} \mathrm{yr}^{-1}$ represents a net value of $251 \mathrm{~g} \mathrm{C} \mathrm{m}^{-2} \mathrm{yr}^{-1}$. Contrasting this with our estimate of gross bacterial production of $237 \mathrm{~g} \mathrm{C} \mathrm{m}^{-2} \mathrm{yr}^{-1}$ suggests that bacterioplankton in the bay are utilizing an amount of organic carbon equivalent to roughly $94 \%$ of that fixed by phytoplankton on an annual basis.

High rates of bacterial carbon demand relative to in situ carbon fixation have been reported from other aquatic systems (Scavia \& Laird 1987), and this high rate of microbial carbon consumption does not indicate that there is no organic carbon available for other consumers, because as long as the carbon is not remineralized, organic matter can be utilized by bacteria after that same organic matter has been consumed by other organisms (Strayer 1988, Fuhrman 1992). Bacterial 
production in estuaries can also be supported by allochthonous sources of organic carbon. Because $80 \%$ of the organic carbon in the bay is estimated to be produced by phytoplankton (Nixon, et al. 1995), the contribution of allochthonous carbon to bacterial production is probably minimal.

\section{Limitations of the analysis}

The extrapolation from one sampling location to the entire bay may result in a biased estimate of bacterial carbon demand. For comparison with phytoplankton primary production estimates, the Fox Island station was chosen based upon the assumption that a midpoint in the bay is representative of a midrange production estimate. Higher production at the Fox and Dyer Island stations relative to Rose Island and GSO suggests that there is a down-bay gradient in bacterial production values, at least in the mid- to lower bay (Fig. 5a,b). Samples from the head of the bay would be needed to determine whether this is a mid-bay peak or a down-bay gradient. Measurements from other studies indicate a down-bay gradient in chl a and primary production (Oviatt et al. 2002). The Fox Island samples were all taken within the first meter of the water column, and use of a surface value could also result in an over estimate of total carbon demand (Fig. 5d).

A literature value of 0.35 was used to convert net bacterial carbon production to gross carbon demand. There is a great deal of variability in this parameter (del Georgio \& Cole 1998) and even in estuaries there is evidence that it can be substantially lower than 0.35 (Middelboe \& Søndergaard 1993). Site-specific estimates of in situ bacterial growth efficiencies could further constrain this value for Narragansett Bay and improve the carbon consumption estimates. In the conversion of leucine incorporation to carbon production an isotope dilution factor of 2 was used, based upon the empirical results reported by Simon \& Azam (1989). Carbon production would be less if the isotope dilution factor was lower in this system.

Until more sampling is performed, the time series at Fox Island represents our best estimate of annual bacterial carbon demand in Narragansett Bay. Since the measurement of bacterial production is labor intensive and requires the use of radioisotopes, it is not routinely measured. For this reason, establishing relationships with other more commonly measured parameters would allow researchers to estimate bacterial production from other datasets. In this study, no correlation was found with chl $a$, but a positive correlation was found with temperature. Over the entire dataset, the equation:

$$
\log (\mathrm{BP}+1)=0.045 T+0.71
$$

(where BP is bacterial production in $\mu \mathrm{g} \mathrm{Cl}^{-1} \mathrm{~d}^{-1}$ and $T$ is temperature in ${ }^{\circ} \mathrm{C}$ ) had an $\mathrm{r}^{2}$ of 0.49 (Fig. 3).

Clearly, there is variability in bacterial production that this regression does not capture, and to better model bacterial production the impacts of bactivory, viral lysis and organic carbon availability would need to be constrained. It is notable that a regression using one parameter, temperature, is able to capture $\sim 1 / 2$ of the variability in bacterial production in a system as dynamic as Narragansett Bay. The establishment of this relationship depends on the use of regression analyses, so it describes correlation rather than causation. The data presented here will allow us to begin to incorporate location-specific estimates of bacterial production into Narragansett Bay carbon flow models using readily available data on water temperature.

Acknowledgements. This work was funded in part by Rhode Island Sea Grant (R/ES-981C) to D.C.S., and by the State of Rhode Island and Providence Plantations. We thank P. Hargraves, M. McFarland and K. Joppe-Mercure for the chl a data and S. Nixon's group for the opportunity to collect samples during the summer of 2000. The comments by 3 anonymous reviewers on a previous draft of this paper are greatly appreciated.

\section{LITERATURE CITED}

Autio R (1998) Response of seasonally cold-water bacterioplankton to temperature and substrate treatments. Estuar Coast Shelf Sci 46:465-474

Bence JR (1995) Analysis of short time series: correcting for autocorrelation. Ecology 76:628-639

Coffin RB, Sharp JH (1987) Microbial trophodynamics in the Delaware Estuary. Mar Ecol Prog Ser 41:253-266

Cole JJ, Findlay S, Pace ML (1988) Bacterial production in fresh and saltwater ecosystems: a cross system overview. Mar Ecol Prog Ser 43:1-10

del Georgio PA, Cole JJ (1998) Bacterial growth efficiency in natural aquatic systems. Annu Rev Ecol Syst 29:503-541

Ducklow H, Shiah F (1993) Bacterial production in estuaries. In: Ford TE (ed) Aquatic microbiology an ecological approach. Blackwell Scientific Publications, Boston, p 261-287

Fuhrman JA (1992) Bacterioplankton roles in cycling organic matter: the microbial food web. In: Falkowski PG, Woodhead AD (eds) Primary productivity and biogeochemical cycles in the sea. Plenum Press, New York, p 361-383

Hobbie JE, Cole JJ (1984) Response of a detrital foodweb to eutrophication. Bull Mar Sci 35:357-363

Hoch MP, Kirchman DL (1993) Seasonal and inter-annual variability in bacterial production and biomass in a temperate estuary. Mar Ecol Prog Ser 98:283-295

Hollibaugh JT (1979) Metabolic adaptation in natural bacterial populations supplemented with selected amino acids. Estuar Coast Mar Sci 9:215-230

Karentz D, Smayda TJ (1984) Temperature and seasonal occurrence patterns of 30 dominant phytoplankton species in Narragansett Bay over a 20-year period (1959-1980). Mar Ecol Prog Ser 18:277-293 
Kirchman D, K'Nees E, Hodson R (1985) Leucine incorporation and its potential as a measure of protein synthesis by bacteria in natural aquatic systems. Appl Environ Microbiol 49:599-607

Kremer JN, Nixon SW (1978) A coastal marine ecosystem simulation and analysis. Springer-Verlag, Berlin

Lee S, Fuhrman JA (1987) Relationships between biovolume and biomass of naturally derived marine bacterioplankton. Appl Environ Microbiol 53:1298-1303

Li WKW, Dickie PM (1987) Temperature characteristics of photosynthetic and heterotrophic activities: seasonal variations in temperate microbial plankton. Appl Environ Microbiol 53:2282-2295

Li WKW, Morris I (1982) Temperature adaptation in Phaeodactylum tricornutum Bohlin: photosynthetic rate compensation and capacity. J Exp Mar Biol Ecol 58:135-150

Lorenzen CJ (1966) A method for the continuous measurement of in vivo chlorophyll concentrations. Deep-Sea Res 13:223-227

Manly FJ (2001) Randomization bootstrap and Monte Carlo methods in biology, 2nd edn. CRC Press, Boca Raton, FL

Middelboe M, Søndergaard M (1993) Bacterioplankton growth yield: seasonal variations and coupling to substrate lability and beta -glucosidase activity. Appl Environ Microbiol 59:3916-3921

Nedwell DB (1999) Effect of low temperature on microbial growth: lowered affinity for substrates limits growth at low temperature. FEMS Microbiol Ecol 30:101-111

Nixon SW, Granger SL, Nowicki BL (1995) An assessment of the annual mass balance of carbon nitrogen, and phosphorus in Narragansett Bay. Biogeochemistry 31:15-61

Noble RT, Fuhrman JA (1998) Use of SYBR Green I for rapid epifluorescence counts of marine viruses and bacteria. Aquat Microb Ecol 14:113-118

Oviatt C, Keller A, Reed L (2002) Annual primary production in Narragansett Bay with no bay-wide winter-spring phytoplankton bloom. Estuar Coast Mar Sci 54:1013-1026

Pilson MEQ (1985) On the residence time of water in Narragansett Bay. Estuaries 8:2-14

Pomeroy LR, Wiebe WJ (2001) Temperature and substrates as interactive limiting factors for marine heterotrophic bacteria. Aquat Microb Ecol 23:187-204

Pomeroy L, Wiebe W, Deibel D, Thompson R, Rowe G, Pakulski J (1991) Bacterial responses to temperature and substrate concentration during the newfoundland spring bloom. Mar Ecol Prog Ser 75:143-159

Prosser CL (1986) Adaptational biology: molecules to organisms. John Wiley \& Sons New York

Pyper BJ, Peterman RM (1998) Comparison of methods to

Editorial responsibility: Bess Ward,

Princeton, New Jersey, USA account for autocorrelation in analyses of fish data. Can J Fish Aquat Sci 55:2127-2140

Scavia D, Laird GA (1987) Bacterioplankton in Lake Michigan: dynamics controls, and significance to carbon flux. Limnol Oceanogr 32:1017-1033

Shiah FK, Ducklow HW (1994a) Temperature regulation of heterotrophic bacterioplankton abundance production, and specific growth rate in Chesapeake Bay. Limnol Oceanogr 39:1243-1258

Shiah FK, Ducklow HW (1994b) Temperature and substrate regulation of bacterial abundance production and specific growth rate in Chesapeake Bay, USA. Mar Ecol Prog Ser 103:297-308

Sieburth J (1967) Seasonal selection of estuarine bacteria by water temperature. J Exp Mar Biol Ecol 1:98-121

Simon M, Azam F (1989) Protein content and protein synthesis rates of planktonic marine bacteria. Mar Ecol Prog Ser 51:201-213

Simon M, Wünsch C (1998) Temperature control of bacterioplankton growth in a temperate large lake. Aquat Microb Ecol 16:119-130

Smayda TJ (1985) Narragansett Bay: variability and change in environment and phytoplankton dynamics over a 23year period. Estuaries 8:86-98

Smith DC, Azam F (1992) A simple economical method for measuring bacterial protein synthesis rates in seawater using ${ }^{3} \mathrm{H}$-leucine. Mar Microb Food Webs 6:107-114

Smith DC, Steward GF, Long RA, Azam F (1995) Bacterial mediation of carbon fluxes during a diatom bloom in a mesocosm. Deep-Sea Res Part II 42:75-97

Strayer D (1988) On the limits to secondary production. Limnol Oceanogr 33:1217-1220

White PA, Kalff J, Rasmussen JB, Gasol JM (1991) The effect of temperature and algal biomass on bacterial production and specific growth rate in freshwater and marine habitats. Microb Ecol 21:99-118

Wright RT, Coffin RB (1983) Planktonic bacteria in estuaries and coastal waters of northern Massachusetts: spatial and temporal distribution. Mar Ecol Prog Ser 11:205-216

Yentsch CS, Menzel DW (1963) A method for the determination of phytoplankton chlorophyll and phaeophytin by fluorescence. Deep-Sea Res 10:221-231

Yoon WB, Rosson RA (1990) Improved method of enumeration of attached bacteria for study of fluctuation in the abundance of attached and free-living bacteria in response to diel variation in seawater turbidity. Appl Environ Microbiol 56:595-600

Zar JH (1999) Biostatistical analysis. Prentice Hall, Upper Saddle River, NJ

Submitted: December 15, 2002; Accepted: January 23, 2004 Proofs received from author(s): April 7, 2004 